\title{
Physiology of cashew plants grown under adverse conditions
}

\author{
Marlos A. Bezerra ${ }^{1 *}$, Claudivan F. de Lacerda ${ }^{2}$, Enéas Gomes Filho ${ }^{3}$, Carlos E. B. de Abreu ${ }^{3}$ and \\ José T. Prisco ${ }^{3}$
}

\begin{abstract}
${ }^{1}$ Embrapa Agroindústria Tropical, Lab. Fisiologia Vegetal, Fortaleza-CE, Brazil. ${ }^{2}$ Departamento de Engenharia Agrícola, Universidade Federal do Ceará, Fortaleza-CE, Brazil. ${ }^{3}$ Departamento de Bioquímica e Biologia Molecular, Universidade Federal do Ceará, Fortaleza-CE, Brazil. *Corresponding author: marlos@cnpat.embrapa.br
\end{abstract}

Received: 28 February 2008; Accepted: 04 March 2008

\begin{abstract}
The cashew (Anacardium occidentale L.) is an important crop for semi-arid agriculture and contributes to the social and economical development of several world regions, including the northeast of Brazil. In spite of its importance, very few studies aim to understand the effects of abiotic stresses on the development and yield of the cashew. This review covers the research on cashew ecophysiology, with emphasis on the effects of water and salt stress on its development, mineral nutrition and gas exchange processes. The results presented here were obtained at different plant growth stages and under different environmental conditions of soil and climate. The ecophysiological significance of this information is also discussed.
\end{abstract}

Key words: Anacardium occidentale, development, salt stress, water deficit

Fisiologia do cajueiro cultivado sob condições adversas. O cajueiro (Anacardium occidentale L.) é uma cultura de grande importância para a agricultura de regiões semi-áridas, contribuindo para o desenvolvimento sócio-econômico de diversas regiões do mundo, incluindo a região nordeste do Brasil. Apesar de sua importância, poucos são os estudos visando à compreensão dos efeitos dos fatores abióticos sobre o desenvolvimento e a produtividade dessa cultura. Nesta revisão, são apresentadas informações científicas sobre a ecofisiologia do cajueiro, dando ênfase aos efeitos dos estresses hídrico e salino sobre os processos de desenvolvimento, nutrição mineral e trocas gasosas. Os resultados apresentados foram obtidos em experimentos com plantas em diferentes estádios de desenvolvimento e sob diferentes condições de solo e clima, de modo que essa complexidade é também discutida no texto.

Palavras-chave: Anacardium occidentale, desenvolvimento, estresse hídrico, estresse salino

\section{INTRODUCTION}

The cashew (Anacardium occidentale), belongs to the Anacardiaceae family, which is composed of some 60 to 74 genera and 400 to 600 species. This family is characterized by resinous conduits in the cortex and wood, where resin is produced, although exudation also occurs from the leaves, flowers and fruits.

The discussion of cashew's origin involves circumstantial evidence, such as that based on the oldest bibliographic references, geographic distribution, ecological behavior, variation patterns of the species, and human usage, among others. In the literature, however, there is no clear distinction between the natural and cultivated dispersion of the plant. Even though the Amazon and the Cerrados of central Brazil are centers of dispersion for the Anacardium genus (Mitchel and Mori 1987), the greatest diversity of the species with economical potential exists in the northeast of Brazil. This has led several authors to infer that the northeast of Brazil is the region of origin for the commercial species (Barros et al., 2002). 
Currently the cashew plant is dispersed over an extensive intertropical zone within parallels $27^{\circ} \mathrm{N}$, in the southeast Florida, and $28^{\circ} \mathrm{S}$, in South Africa (Vieira et al., 2005). The greatest diversity can be found in the various ecosystems of northeastern Brazil, principally along the coastal zones, where it forms part of beach and dune vegetation and the restinga (Barros et al., 2002).

In nature, two types of cashew trees exist classified as A. occidentale L. species, each defined by size and denominated as the common type and the dwarf type. The common cashew tree is more widespread and much taller, with a height varying from 8 to $15 \mathrm{~m}$ and a crown span that can reach $20 \mathrm{~m}$ (Paiva et al., 2003). The individual productive capacity of the common cashew tree varies greatly, with plants that produce from less than one to more than $100 \mathrm{~kg}$ of nuts per harvest. The weight of the fruit also varies greatly, ranging from 3 to $33 \mathrm{~g}$, with the weight of the peduncle ranging from 20 to $500 \mathrm{~g}$. The minimum age for stable production is greater than 8 years, and normally between 12 to 14 years. The dwarf cashew tree is characterized by growth that begins earlier in the season, its smaller size and early productivity. Other characteristics that differentiate the dwarf cashew tree from the common type are: a compact and homogenous crown, with an average span reaching approximately twice the height; smaller, lighter green leaves; smaller stem diameter; initial branches closer to the ground; early seasonal flowering; a prolonged period of fructification; smaller nuts; and generally larger peduncles (Barros, 1988). Nut weight in natural populations varies from 3 to $10 \mathrm{~g}$ and the peduncle (cashew apple) from 20 to $160 \mathrm{~g}$, thus showing a smaller variability in relation to the common type (Vieira et al., 2005). The individual reproductive capacity of the dwarf type is also lower, with maximum known productions no higher than $65 \mathrm{~g}$ of nuts per harvest (Barros, 1995).

The cultivation of the cashew tree is directed towards production of the cashew nut, one of the most commercialized edible nuts available on the international market. In 2005, the worldwide production of nuts was approximately 2.8 million tons, generating around $1,284,000$ tons of cashew products with a commercial value of 1.8 billion dollars (FAO, 2007). During the same year, Brazil exported 98,000 tons of cashew-derived products at a value of US $\$ 181.6$ million. The United
States was the largest buyer from Brazil, consuming an average of $67 \%$, followed by the European Union at $12 \%$ and Canada at $8 \%$ (SECEX, 2007). The largest producers of cashews are Vietnam, India, Brazil, Nigeria and Indonesia (FAO, 2006). However, the largest consumers of cashews are countries with a high per capita income, such as France, Germany, Italy, the United States, Canada and Spain (Vieira et al., 2005). According to the FAO (2006), Brazil is the third largest world producer of nuts with an annual production of 251,268 tons. Approximately 700,000 ha are used for cashew cultivation in various regions of the country, though these are largely concentrated in the northeast. The northeast alone is responsible for $94 \%$ of the national production, with the largest plantations in the coastal regions of Ceará, Piauí and Rio Grande do Norte states (Vieira et al., 2005). The most significant problem of cashew cultivation in the northeast of Brazil has been the low productivity of orchards, currently at less than $220 \mathrm{~kg}$ of nuts per hectare. For this reason, research programs on genetic improvement have given priority to creating cultivars that are more productive in a diversity of environments.

The cashew tree grows well under dry farming conditions, and its cultivation is concentrated in intertropical regions that normally present soil of low fertility and sometimes high salinity. Furthermore, in most of these regions the climate is characterized by high temperatures with low and irregular precipitation, providing insufficient water for plants over the greater part of the year. This explains the fact that only $1 \%$ of the nearly 3.4 million hectares used for cultivating cashews in the world (FAO, 2007) are using irrigation. In addition, the majority of the cashew orchards continue to be managed using technologically unsophisticated practices.

Despite the economic importance of cashew, few studies have sought to understand the physiological aspects of its development and productivity, especially under adverse conditions. In this review, the focus will be on the ecophysiology of the cashew, particularly under conditions of water and salt stress. Emphasis will be given to studies with plants at various stages of development and under different soil and climate conditions, involving aspects of seed germination, seedling establishment, development, mineral nutrition and gas exchange. 


\section{CASHEW SEED GERMINATION AND SEEDLING ESTABLISHMENT}

Germination is a process that begins with the absorption of water by the seed and initiates a series of events, such as: the hydration of proteins, respiration, synthesis of macromolecules and cellular elongation, leading to radicle emersion and seedling establishment (Bewley and Black, 1994). In the dwarf cashew tree, the strictu sensu germination ends when the seeds reach a moisture level of approximately $50 \%$ and radicle emergence occurs. However, the proportion and quantity of water absorbed can be influenced by intrinsic factors, such as seed (nut) vigor and resistance of the seed (nut) coat (Mayer and Poljakoff-Mayber, 1989), and by environmental factors, such as soil texture, temperature and osmotic stress (Kaya et al., 2006; Tommasia et al., 2006; Domènech and Vilà, 2008; Sharma and Amritphale, 2008). The optimal temperature for cashew seed germination is high, around $35^{\circ} \mathrm{C}$, as might be expected for a plant adapted to tropical climates (Rocchetti and Panerai, 1968 apud Cavalcanti Junior, 1994).

Cashew seed germination and seedling establishment under conditions of stress: Although the process of seed germination is highly dependent on water absorption, the literature is devoid of relevant studies concerning the effects of water stress on cashew seed germination.

Salinity affects seed germination by inhibiting water absorption and cellular extension (Kayani et al., 1990; Franco et al., 1993; Katembe et al., 1998; Torres et al., 2000; Al-Karaki, 2001; Almansouri et al., 2001). This may be due to the reduction in water absorption during the imbibition phase or the excessive absorption of toxic ions, especially $\mathrm{Na}^{+}$and $\mathrm{Cl}^{-}$(Prisco and O'Leary, 1970), which alter metabolism by inhibiting or delaying mobilization of storage reserves and damaging the membrane system of the embryonic axis (Prisco et al., 1981; Gomes-Filho and Prisco, 1983; Chartzoulakis and Klapaki, 2000; Murillo-Amador et al., 2002).

In the dwarf cashew tree, the final percentage of germination is only affected by very high levels of salts (Bezerra et al., 2002; Carneiro et al., 2002, E.C. Marques, unpublished results). However, under salinity, retardation occurs at the beginning of the germination process, consequently the average time of germination rose from $9 \mathrm{~d}$ under control conditions to $10.6 \mathrm{~d}$ (E.C.
Marques, unpublished results). Germination retardation appears to be the result of a reduction in the water potential of the soil solution, caused by an increase in soluble salts concentration, though it is not known if this is due simply to the osmotic effects of the salts or if it is also related to the toxicity of specific ions.

The effects of salinity on seed germination and seedling establishment could also be the result of the influence of salts on metabolic processes, such as the mobilization of the stored reserves for the growing embryonic axis. The main reserves of the cashew seeds are lipids, followed by carbohydrates, proteins and other constituents (Johnson, 1973 apud Barros, 1995). Germination and seedling establishment of cashew under water and saline stresses led to the inhibition of mobilization of the cotyledons reserves, principally the lipids, resulting in reduction of embryonic axis growth (Oliveira, 2001; E.C. Marques and T.D. Almeida, unpublished results).

In oleaginous species, the embryonic axis directly affects the mobilization of lipids, both through the source-sink relationship and the production of hormones, which assures that lipid mobilization and seedling growth are synchronized processes (Trelease and Doman, 1984). Consequently, salinity could inhibit seedling development through the inhibition of enzymes involved in the mobilization of lipid reserves of the seed. However, significant alterations have not been observed for lipid content nor the activity of isocitrate lyase and malate synthase enzymes in cotyledons of dwarf cashew seedlings under salt stress applied throughout seed germination and seedling establishment (E.C. Marques, unpublished results). Such results show that the dwarf cashew is more tolerant to salinity during germination than during later stages of seedling development (Carneiro et al., 2002; E. C. Marques, unpublished results), as observed for other glycophytes, (Prisco and O’Leary, 1970; Maas and Hoffman, 1977).

\section{MINERAL NUTRITION OF CASHEW PLANTS}

The acquisition of minerals by plants depends, among other factors, on the mineral reserve of the soil, the morphology of the root system, plant-microorganism 
interactions, and on the physical and chemical characteristics of the soil. Alterations in the chemical characteristics of the soil, such as acidity or alkalinity, water deficit, excess of salts or the presence of aluminum at toxic levels, have a negative effect on the acquisition of minerals by the majority of plants. So, only plants that have developed tolerance mechanisms to these abiotic stresses can grow and survive in such inhospitable environments. On the other hand, alterations in the physical characteristics of the soil, such as soil compactness, could provoke hypoxia or anoxia and decrease the volume of soil explored by the root system, and finally affect ion uptake and plant growth.

Various studies have demonstrated that the cashew tree responds to the application of mineral nutrients, though the responses are significantly affected by plant age, the genotype utilized, the conditions of cultivation (soil and climate) and of the crop management (Barros et al., 1984; Glosh, 1989; Ximenes, 1995; Bezerra et al., 1999; Crisóstomo et al., 2005). The crop develops well under semi-arid conditions, in which the problems associated with water availability and salt excess in the root environment are common. These two factors interfere with the acquisition of nutrients, in that the levels of nutrients in the plants are affected both by direct effects on absorption and transportation processes and by indirect effects associated with a reduction of growth of the various plant organs including the root system.

The effect of salinity on plant nutrition depends on the types of salts that predominate in the cultivation environment which can result in a deficiency of essential nutrients and an excess of toxic ions. These changes under salt stress are accompanied by a loss of structural and functional integrity of the cellular membranes, a reduction in activity of various vital enzymes, and a diminished capacity of the roots to absorb nutrients (Zhu, 2001). On the other hand, water deficit reduces the extraction of nutrients from the soil, limiting the solubilization of nutrients in the root environment and altering the morphology of the root system (Kramer and Boyer, 1995). It should be added that the effects of excess salt and water deficit depend on various factors, including the species under study and the stage of development at which the plants are submitted to these stress factors.
Effects of salinity on mineral nutrition of young cashew plants (nursery plants): Studies of mineral nutrition during the initial phase of cashew plant development should take into consideration the quantity of nutrients contained in the cotyledons, in view of the size and relatively high nutrient content in these reserve organs. Although the extraction of nutrients from the substrate follow this decreasing order: $\mathrm{N}>\mathrm{K}>\mathrm{Ca}>\mathrm{Mg}>\mathrm{P}>\mathrm{S}$ (Ximenes, 1995; Lima et al., 2003), the macronutrients contained in the cotyledons can provide around $54 \%$ of $\mathrm{N}, 45 \%$ of $\mathrm{P}, 17 \%$ of $\mathrm{K}, 1 \%$ of $\mathrm{Ca}, 16 \%$ of $\mathrm{Mg}$ and $36 \%$ of $\mathrm{S}$ necessary for seedling development for up to $75 \mathrm{~d}$ after planting (Ximenes, 1995). These percentages are even higher in the case of a seedling at $30 \mathrm{~d}$ from emergence, an age at which they can be used as rootstock.

When the objective is to study the influence of stresses on the nutrition of seedlings, it is also necessary to pay special attention to the substrate. For cashew seedlings cultivated in different substrates, salinity involving $\mathrm{NaCl}$ reduces the levels of $\mathrm{K}^{+}$in the plant and simultaneously promotes the accumulation of $\mathrm{Na}^{+}$and $\mathrm{Cl}^{-}$ (Table 1) to toxic levels (Mesquita et al., 2007). However, the reductions in leaf $\mathrm{K}^{+}$concentrations were significant only when the nutrient solution was used in a hydroponics system. The ions $\mathrm{Na}^{+}$and $\mathrm{K}^{+}$accumulate more in seedlings cultivated in the traditional substrate (used by growers), whereas the accumulation of $\mathrm{Cl}^{-}$, in absolute values, occurs to the same extent using the traditional substrate as with nutrient solution. On the other hand, salinity caused a linear increase in the concentrations of $\mathrm{Na}^{+}$and $\mathrm{Cl}^{-}$in different parts of the plant, with seedlings cultivated in nutrient solutions presenting a greater percentage increase in relation to control plants. In the experiments conducted in vermiculite, the $\mathrm{K}^{+}$leaf concentration was unaffected by the salt treatments, a result which has been observed in other studies (Bezerra et al., 2002; Alencar et al., 2007). In addition, it has been verified that these results depend on the time of stress application, as short durations of stress do not appear to significantly alter the levels of $\mathrm{K}^{+}$in the leaf tissues (Viégas et al., 2001).

The mode that salt is applied to a cashew plant can affect ion accumulation. According to Bezerra et al. (2005), the application of saline solutions directly on leaves results in a significant increase in leaf concentration of $\mathrm{Na}^{+}$and $\mathrm{Cl}^{-}$(Figure 1). Such an effect 
was not observed in plants where saline solutions were applied to the roots, where the increase of these ions in the leaf was small (Figure 1). Indeed, the differences between the two modes of application were significant for all salinity treatments, excluding that of $0.5 \mathrm{dS} \mathrm{m}^{-1}$. In addition, the plants that received saline solutions via the leaves showed a greater reduction in leaf area and dry matter together with the greater leaf accumulation of $\mathrm{Na}^{+}$ and $\mathrm{Cl}^{-}$, reinforcing the hypothesis that plant growth inhibition was further intensified by the toxic effect of these ions.

Salinity also appears to affect the metabolism of mineral nitrogen. It primarily affects the uptake, transport and assimilation of $\mathrm{NO}_{3}^{-}$, and the reduction in absorption of $\mathrm{NO}_{3}^{-}$has been linked to competition with the $\mathrm{Cl}^{-}$ion (Marschner, 1995). In cashew seedlings, Viégas et al. (2004) found that salinity causes reductions in the activity of enzymes responsible for nitrate reduction, due to indirect osmotic effects inducing decreases in sap flow. According to these authors, the assimilatory reduction of $\mathrm{NO}_{3}^{-}$has taken on a central role in plants exposed to salinity. This ion is generally the principal form of nitrogen available to crops under field conditions where plant productivity is substantially influenced by the acquisition and reduction of this ion followed by its incorporation in amino acids and proteins.

Table 1. Concentrations of $\mathrm{Cl}^{-}, \mathrm{Na}^{+}$, and $\mathrm{K}^{+}$in leaves, stems and roots of dwarf cashew plantlets grown in different substrates and irrigated with saline solutions of different $\mathrm{NaCl}$ concentrations. Means $(n=5)$ in columns with different capital letters are significantly different between salt levels and means with different small letters are significantly different between substrates at $P \leq 0.05$ (from Mesquita et al., 2007).

\begin{tabular}{|c|c|c|c|c|c|c|c|c|c|c|}
\hline \multirow{3}{*}{ Substrate } & \multirow{3}{*}{$\begin{array}{c}\text { Treatments } \\
(\mathrm{mM})\end{array}$} & \multicolumn{3}{|c|}{ Leaf } & \multicolumn{3}{|c|}{ Stem } & \multicolumn{3}{|c|}{ Root } \\
\hline & & ${ }^{\mathrm{S}} \mathrm{Cl}^{-}$ & $\mathrm{Na}^{+}$ & $\mathrm{K}^{+}$ & $\mathrm{Cl}^{-}$ & $\mathrm{Na}^{+}$ & $\mathrm{K}^{+}$ & $\mathrm{Cl}^{-}$ & $\mathrm{Na}^{+}$ & $\mathrm{K}^{+}$ \\
\hline & & \multicolumn{3}{|c|}{$\mathrm{g} \mathrm{kg}^{-1} \mathrm{DM}$} & \multicolumn{3}{|c|}{$\mathrm{g} \mathrm{kg}^{-1} \mathrm{DM}$} & \multicolumn{3}{|c|}{$\mathrm{g} \mathrm{kg}^{-1} \mathrm{DM}$} \\
\hline \multirow[t]{3}{*}{ Traditional } & 0 & $09.1 \mathrm{Ca}$ & $12.7 \mathrm{Ca}$ & $28.2 \mathrm{Ba}$ & $06.8 \mathrm{Ca}$ & $12.9 \mathrm{Ca}$ & $29.1 \mathrm{Aa}$ & $08.7 \mathrm{Ca}$ & $12.4 \mathrm{Ca}$ & $23.0 \mathrm{Aa}$ \\
\hline & 60 & $27.3 \mathrm{Ba}$ & $38.1 \mathrm{Ba}$ & $26.9 \mathrm{Ba}$ & $17.7 \mathrm{Ba}$ & $38.8 \mathrm{Ba}$ & $21.6 \mathrm{Ba}$ & $21.8 \mathrm{Ba}$ & $44.9 \mathrm{Ba}$ & $14.5 \mathrm{Ba}$ \\
\hline & 120 & $32.5 \mathrm{Aa}$ & $48.6 \mathrm{Aa}$ & $32.3 \mathrm{Aa}$ & $23.6 \mathrm{Ab}$ & $54.2 \mathrm{Aa}$ & $20.9 \mathrm{Ba}$ & $31.9 \mathrm{Aa}$ & $55.9 \mathrm{Aa}$ & $12.5 \mathrm{Ba}$ \\
\hline \multirow[t]{3}{*}{ Vermiculite } & 0 & $08.3 \mathrm{Ca}$ & $15.4 \mathrm{Ca}$ & $12.7 \mathrm{~A}$ & $06.4 \mathrm{Ca}$ & $15.4 \mathrm{Ca}$ & $09.1 \mathrm{Ac}$ & $08.2 \mathrm{Ca}$ & $16.8 \mathrm{Ca}$ & $11.4 \mathrm{Ac}$ \\
\hline & 60 & $16.4 \mathrm{Bb}$ & $27.8 \mathrm{Bb}$ & $12.2 \mathrm{Ab}$ & $15.3 \mathrm{Ba}$ & $31.0 \mathrm{Bb}$ & $07.1 \mathrm{Ab}$ & $23.1 \mathrm{Ba}$ & $37.60 \mathrm{Bb}$ & $07.6 \mathrm{Bb}$ \\
\hline & 120 & $23.3 \mathrm{Ab}$ & $36.6 \mathrm{Ab}$ & $11.7 \mathrm{Ab}$ & $21.3 \mathrm{Ab}$ & $37.6 \mathrm{Ab}$ & $06.6 \mathrm{Ab}$ & $32.5 \mathrm{Aa}$ & $51.8 \mathrm{Aa}$ & $07.6 \mathrm{Bb}$ \\
\hline Nutritve & 0 & $07.1 \mathrm{Ca}$ & $04.4 \mathrm{Cb}$ & $12.5 \mathrm{Ab}$ & $06.8 \mathrm{Ca}$ & $03.0 \mathrm{Cb}$ & $15.5 \mathrm{Ab}$ & $09.3 \mathrm{Ca}$ & $03.8 \mathrm{Cb}$ & $15.4 \mathrm{Ab}$ \\
\hline \multirow[t]{2}{*}{ Solution } & 60 & $18.1 \mathrm{Bb}$ & $26.4 \mathrm{Bb}$ & $07.3 \mathrm{Bc}$ & $18.3 \mathrm{Ba}$ & $27.3 \mathrm{Bb}$ & $07.7 \mathrm{Bb}$ & $24.4 \mathrm{Ba}$ & $25.4 \mathrm{Bb}$ & $10.3 \mathrm{Bb}$ \\
\hline & 120 & $33.5 \mathrm{Aa}$ & $37.0 \mathrm{Ab}$ & $9.7 \mathrm{ABb}$ & $31.9 \mathrm{Aa}$ & $39.4 \mathrm{Ab}$ & $05.0 \mathrm{Bb}$ & $33.2 \mathrm{Aa}$ & $32.7 \mathrm{Ab}$ & $6.8 \mathrm{Cb}$ \\
\hline
\end{tabular}
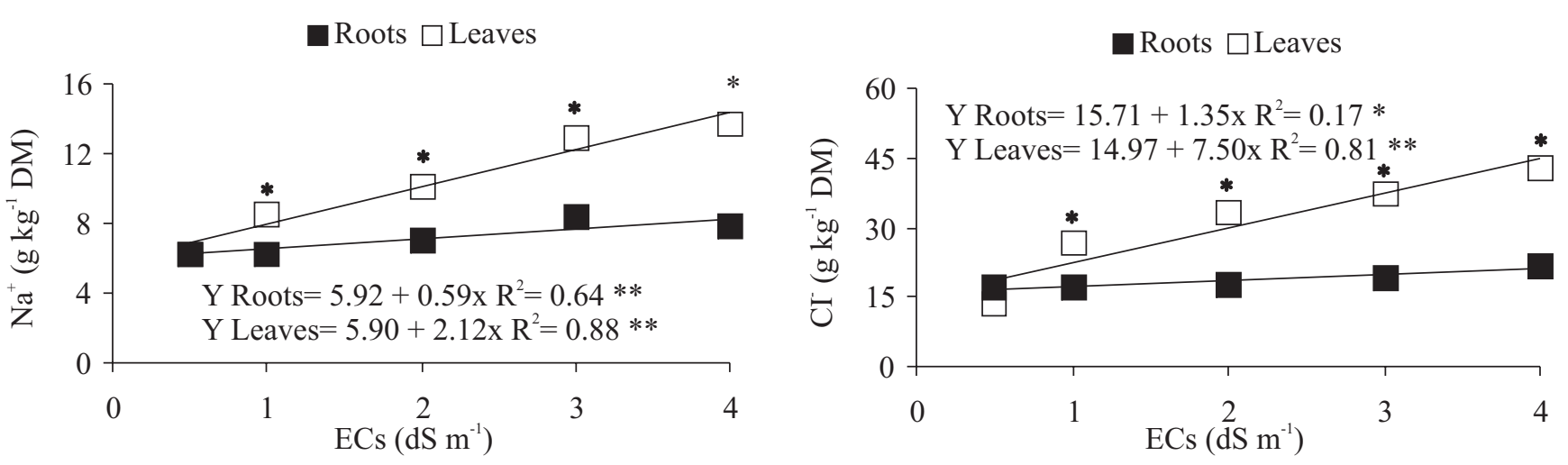

Figure 1. Leaf concentrations of $\mathrm{Na}^{+}$and $\mathrm{Cl}^{-}$of dwarf cashew plants irrigated with saline solutions of different concentrations applied into the root environment or on the leaves. Each point is the mean of four replicates. Ecs $=$ electrical conductivity of the irrigation solution; differences statistically significant at $P \leq 0.01(* *)$ or at $P \leq 0.05(*)$ (redrawn from Bezerra et al., 2005). 
Mineral nutrition of adult cashew plants under stress: The concentrations of minerals in the leaves of adult cashew plants vary as a function of plant age, leaf age, mobility of the nutrient within the plant, season of the year, environmental conditions, and the genotype under study (Kumar et al., 1982; Bezerra et al., 1999). In an experiment performed by Kumar et al. (1982), great variations in the concentration of $\mathrm{N}, \mathrm{P}$ and $\mathrm{K}$ were found in function of leaf age and season for the common cashew plant growing under a dry, non-fertilized regime. These authors also demonstrated that the process of fruit development causes a decrease in the levels of these nutrients in the leaf, which could be a consequence of ion translocation to the developing fruit.

Dwarf cashew plants cultivated under dry and nonfertilized conditions showed variations in leaf concentration of macronutrients along a cycle of production. The variations were associated with leaf age and the phenological changes of the plant over the course of a year (Bezerra et al., 1999). These authors observed increasing levels of N, P, K, Mg and S up to the beginning of the reproductive phase (rainy season), and decreasing thereafter (with the exception of $\mathrm{K}$ which remained unvaried) during flowering and fruit development (dry season). The levels of $\mathrm{Ca}$ also tended to increase with the age of the leaf. Indeed, it was shown that the level of these nutrients was not altered in the leaves of a dwarf cashew plant that received higher doses of $\mathrm{N}$ and $\mathrm{K}$ fertilizer, and at times it was greater in nonfertilized plants. This could be the result of dilution, since fertilized plants presented greater canopy development (Richard, 1993; Crisóstomo et al., 2005). It is also noteworthy that the levels obtained with fertilized plants (Crisóstomo et al., 2005) were not different from those obtained with non-fertilized plants (Bezerra et al., 1999), and this could also be associated with dilution and concentration effects, due to the influence of fertilization on plant growth.

Nutritional stress in adult cashew plants also showed a similar complex response. Guilherme (2006) conducted a 12 -month experiment in an area where the soil type Quartzarenic Neosol predominates using cuttings of the clone CCP 76 grafted on CCP 06 and that had been heavily pruned down to the stem before initiating the experiment. It was observed that after plants were irrigated with water containing different salt concentrations [0.5 (water control), 1.5, 3.0, 6.0 and $9.0 \mathrm{dS} \mathrm{m}^{-1}$ ] only the levels of leaf $\mathrm{Ca}$ and $\mathrm{Na}$ were affected, while the changes in $\mathrm{Mg}, \mathrm{K}, \mathrm{Cl}$ and $\mathrm{P}$ were not significant.

Increases in the levels of $\mathrm{Ca}$ occurred only in the leaves during periods when the reproductive drain was lower (March, June and December in northeastern Brazil), whereas the levels of $\mathrm{Na}$ increased in the new (September) and old (June) leaves (Figure 4). However, the levels of $\mathrm{Na}$ in the leaves did not reach the toxicity limit of this species, since no negative influence was observed on the development of the plant (Guilherme, 2006). It is possible that the increases in the levels of these two ions could have been beneficial for the development of the plant, since $\mathrm{Ca}$ is an essential element for the formation of cell walls, and $\mathrm{Na}$, being more available in the soil due to irrigation with saline water, can substitute $\mathrm{K}$ in some of its less specific functions (Taiz and Zeiger, 2002; Lacerda, 2005). However, in relation to the season when samples were taken for analysis, significant differences occurred for all the measured parameters which reflect the different degrees of ion mobility and age of the sampled leaves (Figures 2, 3 and 4). The concentrations of $\mathrm{K}$ (Figure 2B) were the highest among the analyzed ions, in agreement with its role in the plant, and $\mathrm{K}$ was the first most exported ion by the cashew apple and the second most exported by the nuts (Fragoso et al., 1999). However, K concentration decreased from March to June and this reflects the mobilization of $\mathrm{K}$ to the reproductive parts associated with the aging of leaves during this period (Bezerra et al., 1999). The levels of P (Figure 2A), Mg (Figure 3A), and Cl (Figure 3B) were influenced by the time of sampling, showing a decrease in levels in the leaf renovation period (June) and in the period when a strong reproductive drain was present (September), as well as a greater accumulation in the period after production, when the leaves are maturing (December). On the other hand, the levels of $\mathrm{Na}$ (Figure 4B) and $\mathrm{Ca}$ (Figure 4A) increased with leaf age between March and June, reflecting the major period of accumulation through transpiration flow (Bezerra et al., 1999) together with the presence of these two elements in the irrigation water.

The complexity of the mineral nutrition of adult cashew plants could also be observed when the accumulation of ions was compared for irrigated and nonirrigated plants, cultivated under the same conditions of the experiment described above. When the variations of 

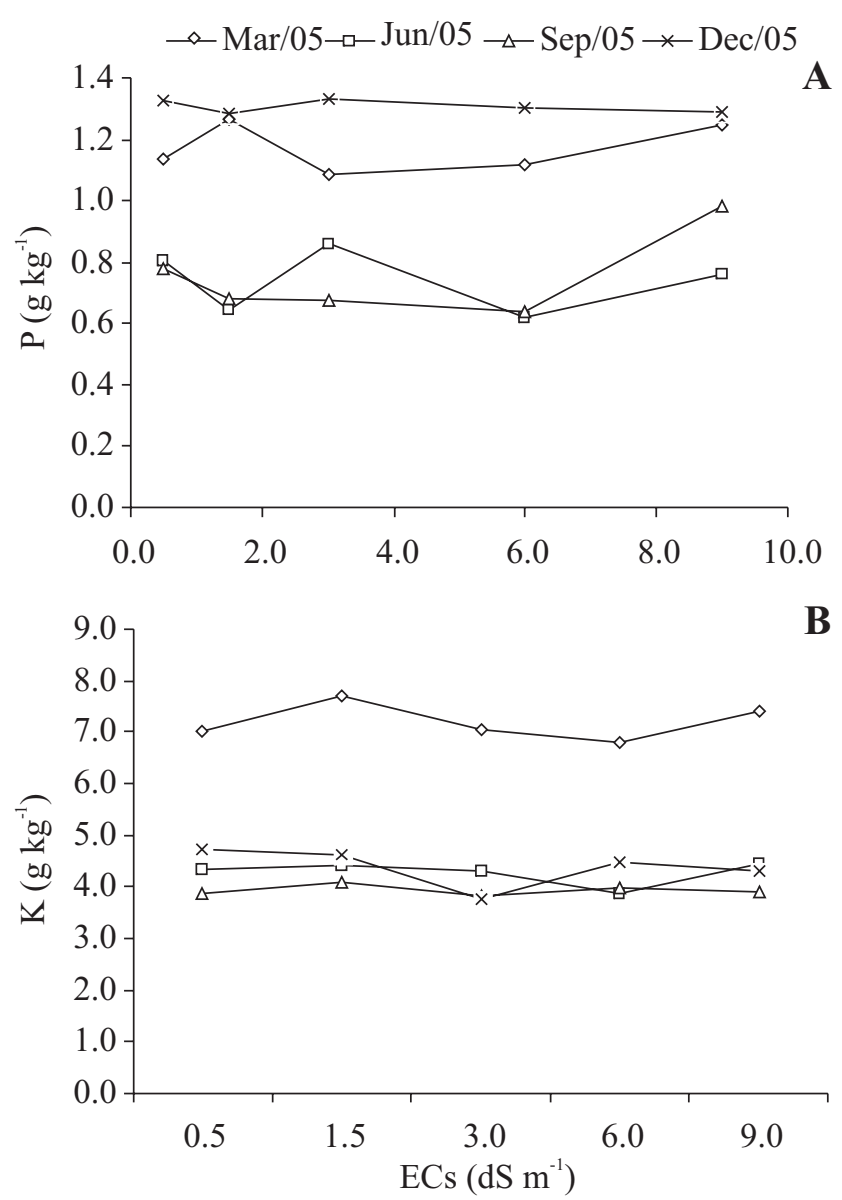

Figure 2. Leaf concentrations of phosphorus (P) and potassium $(\mathrm{K})$ of dwarf cashew plants in function of the time of year and the electrical conductivity (ECs) of the irrigation water. Each point is the mean of four replicates (redrawn from Guilherme et al., 2005, 2006).

the ion levels in dry and irrigated treatments were analyzed, there was a significant difference for $\mathrm{Na}^{+}$ concentration only in October (Figure 5A), when its content per unit dry mass was greater in the irrigated treatment, and in November, when it was lower in this treatment. Chloride, however, was not altered (Figure 5B)

Finally, when comparing the accumulation of $\mathrm{N}$ and $\mathrm{K}$ in adult cashew plants given different doses of these two nutrients, Crisóstomo et al. (2004) observed no difference in leaf content of plants that did not receive $\mathrm{N}$ fertilizer with those that received up to $173 \mathrm{~kg} \mathrm{~N} \mathrm{ha}^{-1}$. On the other hand, fertilization with $73.4 \mathrm{~kg} \mathrm{~K}_{2} \mathrm{O} \mathrm{ha}^{-1}$ resulted in an elevation of leaf $\mathrm{K}$ concentration, when compared to plants to which no K was applied.
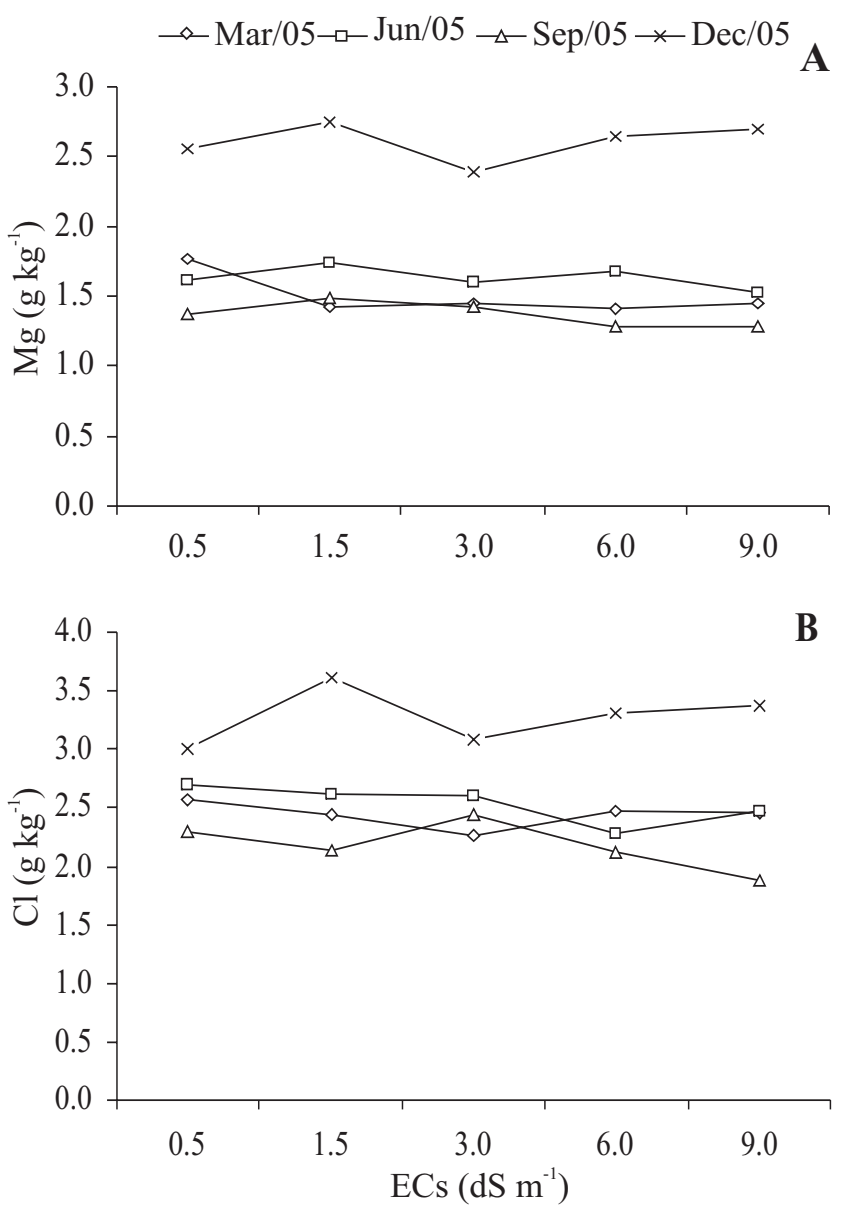

Figure 3. Leaf concentrations of magnesium $(\mathrm{Mg})$ and chloride $(\mathrm{Cl})$ of dwarf cashew plants in function of the time of year and the electrical conductivity (Ecs) of the irrigation water. Each point is the mean of four replicates (redrawn from Guilherme et al., 2005, 2006).

\section{GAS EXCHANGES IN CASHEW PLANTS UNDER STRESS}

The low availability of water in soil has both direct and indirect negative effects on the photosynthetic rate of plants. This could be due to stomatal closure that, in turn, reduces the availability of $\mathrm{CO}_{2}$ inside the mesophyll cells, or due to non-stomatal limitations that diminishes the potential capacity of $\mathrm{CO}_{2}$ assimilation (Lawlor, 2002; Flexas et al., 2004). Nevertheless, stomatal closure appears to be the principal cause of reduced photosynthetic rates (Flexas et al., 2004). Apparently there is no inhibition of photochemical reactions or alterations in the pool of intermediary compounds of the photosynthetic carbon reduction cycle, at least within a 

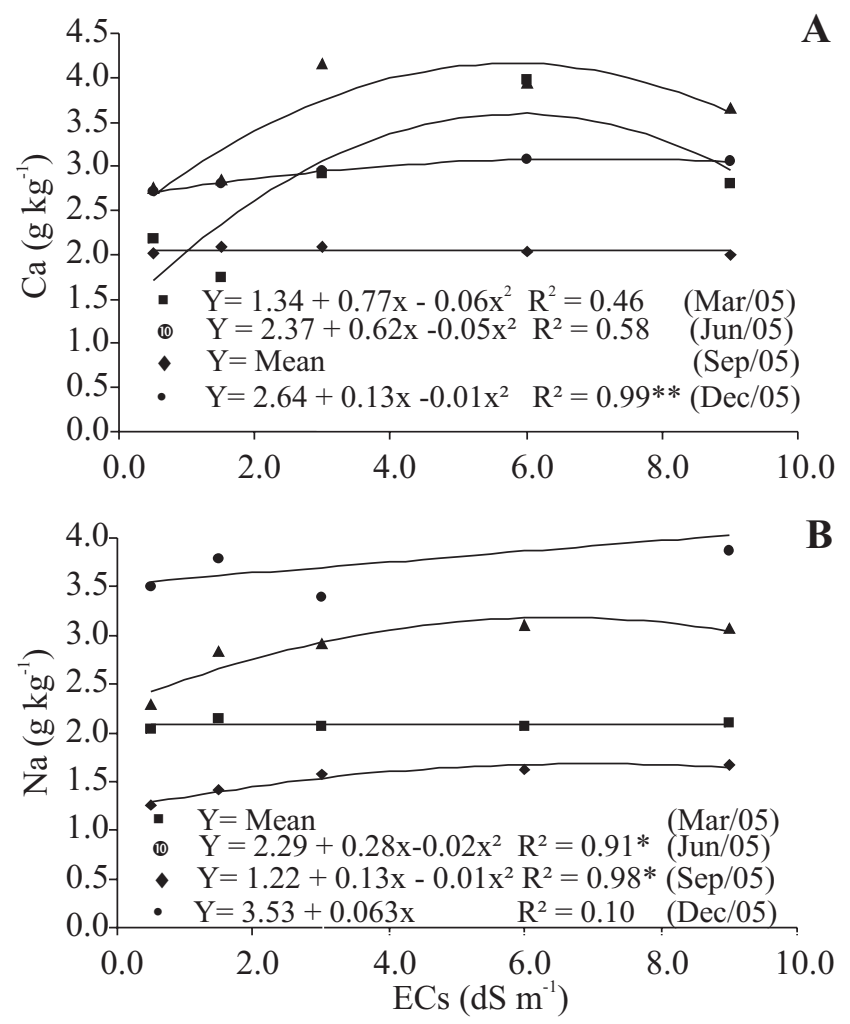

Figure 4. Leaf concentrations of calcium $(\mathrm{Ca})$ and sodium (Na) of dwarf cashew plants in function of the time of year and the electrical conductivity of the irrigation water (ECs) (redrawn from Guilherme et al., 2005, 2006). Statistics as in Figure 1.

change of up to $30 \%$ of the protoplast volume (Chaves, 1991; Pelleschi et al., 1997). Under conditions of salinity gas exchange is chiefly impaired as a consequence of altered physiology and biochemistry of stomata as well as due to effects of salts on photochemical events (Taiz and Zeiger, 2002). Salinity also impairs the transport of photoassimilates and, consequently, the metabolism of carbohydrates, compromising the normal growth and development of plants (Kozlowski, 1997).

Effect of irrigation on cashew tree photosynthesis: Photosynthesis of two-year-old cashew trees cultivated in containers, under irrigation, was greater than those cultivated under the same conditions but without irrigation. The same behavior was observed for stomatal conductance to water vapor such that a close relationship between these two variables was found (Blaikie and Chacko, 1998).

In an experiment with irrigated dwarf cashew plant clones cultivated in the experimental field of Paraipaba, Ceará state (northeastern Brazil), a region whose annual precipitation varies between 600 and $1200 \mathrm{~mm}$, concentrated in the first four months of the year, Oliveira et al. (2006) found an increase in the production of nuts of irrigated plants of around 70\% (the mean over seven years). This increase was strongly correlated with the increase in quantity of nuts produced per plant. Nevertheless, this increase in production does not appear to be related to increments in photosynthetic rates per unit leaf area since Lima et al. (2007) did not find differences in photosynthetic rates of irrigated and nonirrigated dwarf cashew plants in a study carried out in the same region. Similarly, in an experiment conducted in a different region of Ceará, Amorim (2007) observed that the parameters related to gas exchange did not differ significantly between irrigated and non-irrigated adult cashew plants. It should be noted that in both cases, gas exchanges were monitored over a productive cycle and the average rate of net photosynthesis was around 15 $\mu \mathrm{mol} \mathrm{m} \mathrm{m}^{-2} \mathrm{~s}^{-1}$. It must be emphasized, however, that in both studies quoted above the plants were grown in regions whose annual precipitation during the experimental period was around $1000-1200 \mathrm{~mm}$ with a shallow water table (average depth of $15 \mathrm{~m}$ ). Since the cashew tree is a plant adapted to semi-arid regions, it appears in these conditions that the non-irrigated plants did not experience a severe water deficit, which could explain their relatively elevated rate of photosynthesis. Similarly, the average stomatal conductance of the non-irrigated plants showed a mean reduction of $5 \%$ in relation to the irrigated control during the period of greatest vapor pressure deficit. In fact, for dwarf cashew plants cultivated in drier conditions such as that of the semi-arid region of Piaui State, northeastern Brazil, with a low average precipitation, an elevated rate of evapotranspiration and a deep water table - conditions in which the plants would certainly suffer a water deficit - the average photosynthetic rate of the cashew plants was 10 $\mu \mathrm{mol} \mathrm{m} \mathrm{m}^{-2} \mathrm{~s}^{-1}$ (unpublished results). Consistent with these data, Schaper et al. (1996) in northern Australia also found significant differences in photosynthetic rates of irrigated and non-irrigated cashew trees, with higher differences during October, when the level of water in the soil was at its lowest and the plants were in full fruit. 

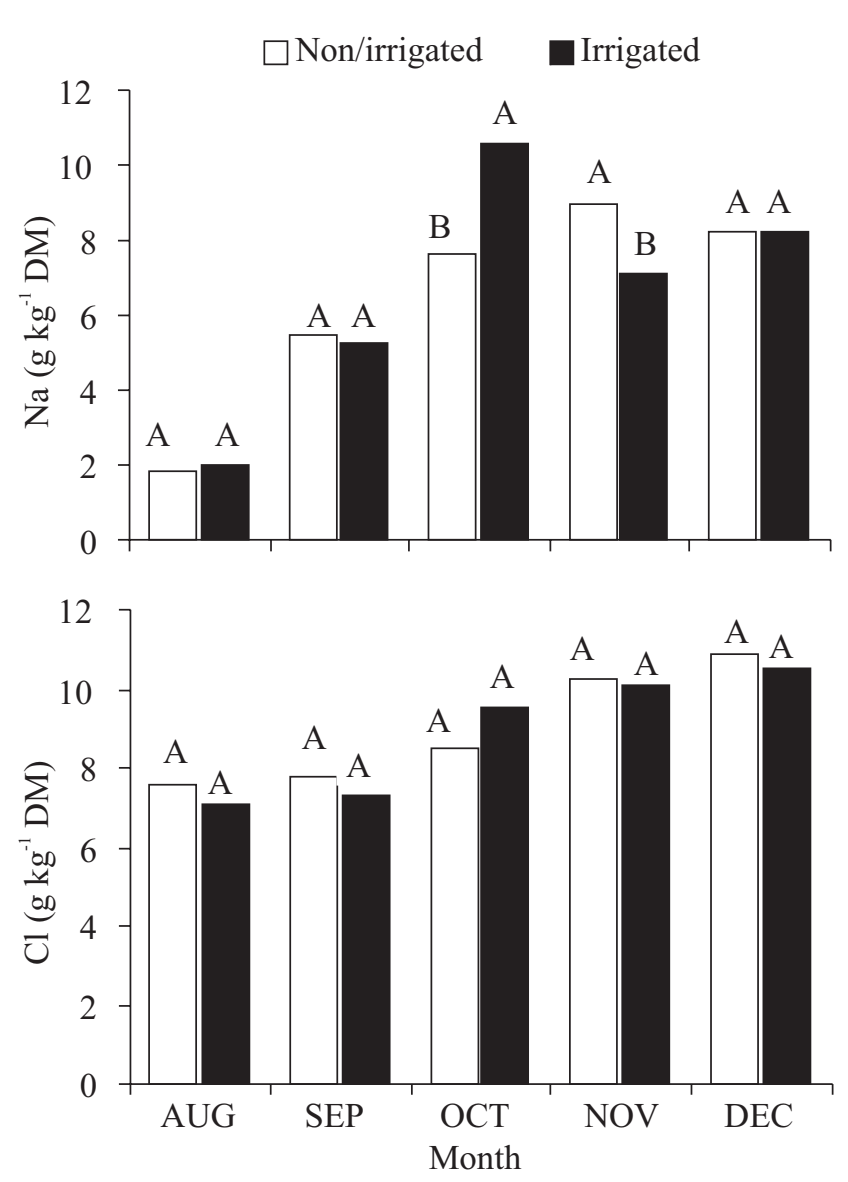

Figure 5. Leaf concentrations of sodium $(\mathrm{Na})$ and chloride (Cl) of dwarf cashew plants in function of the time of year and the irrigation. Means $(n=4)$ represented by columns with the same letter are not significantly different by the Tukey test $(P>0.05)$ (redrawn from Amorim, 2007).

Effect of salinity on cashew photosynthesis: The photosynthesis of cashew seedlings is strongly affected by salinity. Dwarf cashew seedlings that were irrigated with saline solutions for $30 \mathrm{~d}$ after sowing had their photosynthetic rates reduced linearly with increasing salt level, independent on the substrate utilized (Mesquita et al., 2007). Nonetheless, the degree of reduction depended on the substrate utilized, with plants cultivated in vermiculite having a lesser reduction in photosynthetic rate under saline stress than those cultivated in soil and nutritive solutions (Table 2).

In an experiment with grafted plantlets of dwarf cashew, a linear inhibition of photosynthetic rate of seedlings occurred with increasing salinity of the irrigation solutions (Bezerra et al., 2005). This effect was more accentuated in the plants where the solutions were applied to the leaves. In spite of the drastic reduction in photosynthesis of the salt-stressed plants, the limitation to growth does not appear to be due solely to the reduction in photosynthetic capacity of the plants, since under low photosynthesis rates the plants that received salts via the root system maintained their growth rate. The reduction of leaf growth appears to be a consequence of the inhibition of cellular division and expansion (Munns and Termaat, 1986; Munns, 1993), which in turn restricts the leaf area available for photosynthesis, limiting the productive capacity of the plants.

With regard to the effect of salinity on adult cashew plants, the observed response is quite distinct from that seen with seedlings. No significant effect of irrigation water salinity was observed on the photosynthetic rate (Figure 6) in seven-year-old plants of dwarf cashew irrigated with saline water (conductivity up to $9.0 \mathrm{dS} \mathrm{m}^{-1}$ ), which elevated the electrical conductivity of the soil saturation extract up to $9.5 \mathrm{dS} \mathrm{m}^{-1}$, a value considered above the classification limit for saline soils (Richards, 1954). In spite of the elevated levels of salts in the soil, there was no considerable increase of $\mathrm{Na}^{+}$and $\mathrm{Cl}^{-}$in the leaves, which suggests that the cashew tree possesses a mechanism whereby the movement of salt to the aerial parts is avoided. This may be associated with the fact that plants could be absorbing water from deeper layers of soil, alleviating a probable osmotic effect in the layers influenced by localized irrigation. This same behavior was observed by Amorim (2007), who applied saline water with electrical conductivity of up to $12 \mathrm{dS} \mathrm{m}^{-1}$. It should be noted that in both cases, the plants were cultivated in soils with a predominance of quartz sand, with good drainage, and were receiving a good supply of water (saline solutions) and fertilization. Under these conditions, irrigating a cashew tree with salt solution was shown to be viable. However, since the processes of salinization are complex, research projects should be developed in order to define the maximum levels of salt tolerance for the cultivation of cashew trees in various soil types, and that determine the mechanisms developed by adult cashew plants to tolerate such levels of salt. 
Table 2. Photosynthesis rate $\left(\mu \mathrm{mol} \mathrm{m} \mathrm{m}^{-2} \cdot \mathrm{s}^{-1}\right)$ of dwarf cashew plantlets cultivated in different substrates and irrigated with saline solutions of different $\mathrm{NaCl}$ concentrations. Means $(n=5)$ in columns with different capital letters are significantly different between salt levels and means with different small letters are significantly different between substrates at $P \leq$ 0.05 (from Mesquita et al., 2007).

\begin{tabular}{lcrrrr}
\hline Substrate & $\begin{array}{c}\mathrm{NaCl} \\
(\mathrm{mM})\end{array}$ & \multicolumn{5}{c}{ Day of stress } \\
\cline { 2 - 6 } & 0 & $12.6 \mathrm{Aa}$ & $12.3 \mathrm{Ab}$ & $11.7 \mathrm{Ab}$ & 28 \\
\hline Traditional & 0 & $11.4 \mathrm{Aa}$ & $08.2 \mathrm{Bb}$ & $06.5 \mathrm{Bb}$ & $09.8 \mathrm{Ab}$ \\
& 120 & $08.4 \mathrm{Ba}$ & $04.2 \mathrm{Cb}$ & $02.2 \mathrm{Cb}$ & $03.3 \mathrm{Bb}$ \\
Vermiculite & 0 & $14.7 \mathrm{Aa}$ & $15.0 \mathrm{Aa}$ & $14.3 \mathrm{Aa}$ & $01.8 \mathrm{Cb}$ \\
& 60 & $14.0 \mathrm{Aa}$ & $12.3 \mathrm{Ba}$ & $11.44 \mathrm{Ba}$ & $11.2 \mathrm{Aa}$ \\
& 120 & $09.1 \mathrm{Ba}$ & $06.8 \mathrm{Ca}$ & $05.0 \mathrm{Ca}$ & $07.8 \mathrm{Ba}$ \\
Nutritive & 0 & $14.1 \mathrm{Aa}$ & $15.6 \mathrm{Aab}$ & $14.5 \mathrm{Aab}$ & $05.4 \mathrm{Ca}$ \\
Solution & 60 & $10.3 \mathrm{Aa}$ & $09.7 \mathrm{Bab}$ & $08.4 \mathrm{Bab}$ & $09.1 \mathrm{Ab}$ \\
& 120 & $06.4 \mathrm{Ba}$ & $03.5 \mathrm{Cab}$ & $02.9 \mathrm{Cab}$ & $04.4 \mathrm{Bb}$ \\
& & & & $02.1 \mathrm{Cb}$ \\
\hline
\end{tabular}

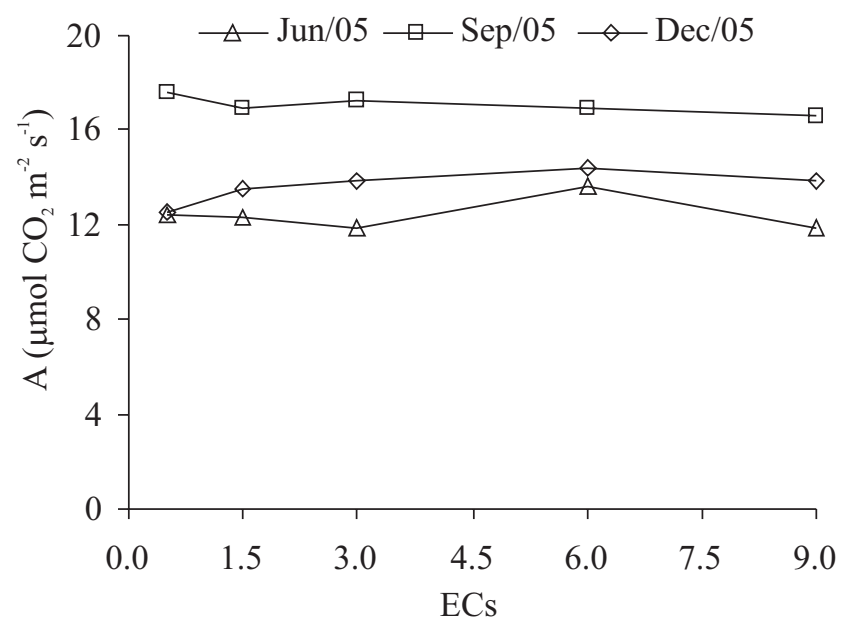

Figure 6. Photosynthesis of dwarf cashew plants in function of the time of year and the electrical conductivity (ECs) of the irrigation water. Means $(n=4)$ were not different by the Tukey test $(P \leq 0.05)$ (redrawn from Guilherme, 2006).

\section{CONCLUDING REMARKS}

The challenge for cashew crop will be to improve yields in marginal lands where the harsh environment strongly limits crop growth and production. Water deficits and salinity associated with supra-optimal temperatures are the most likely environmental factors limiting production. Although there are some promising results revealing the potentialities to expand the cashew crop towards these harsh conditions, this review has shown that we are just beginning to have relevant ecophysiological information on the seed germination, seedling establishment and development, mineral nutrition and gas exchange of the cashew tree grown under water and salt stress. A deep understanding of the ecophysiology of the cashew tree and its impact on science-based crop management and development of new cultivars with superior performance is a challenge to be handled within the near future.

\section{REFERENCES}

Alencar NLM, Pizarro JCA, Prisco JT, Bezerra MA, Gomes-Filho E (2007) Ajustamento osmótico em plântulas de cajueiro anão-precoce (Anacardium occidentale L.) submetidas à salinidade. In: Annals of the Workshop Manejo e Controle da Salinidade na Agricultura Irrigada. Recife, Brazil, CD Room.

Al-Karaki GN (2001) Germination, sodium, and potassium concentrations of barley seeds as influenced by salinity. J. Plant Nutr. 24:511-522.

Almansouri M, Kinet, JM, Lutts S (2001) Effect of salt and osmotic stresses on germination in durum wheat (Triticum durum Desf.). Plant Soil 231:243-254.

Amorim AV (2007) Produção e fisiologia de plantas de cajueiro anão-precoce sob condições de sequeiro e irrigadas com águas salinas. Fortaleza, Universidade Federal do Ceará. M.Sc. dissertation.

Barros LM, Araújo FE, Almeida JIL, Teixeira LMS (1984). A cultura do cajueiro anão. EPACE, Fortaleza (EPACE Documentos 3).

Barros LM (1988) Melhoramento. In: Lima VPMS (ed), A 
Cultura do Cajueiro no Nordeste do Brazil, pp.321-355. BNB/ETENE, Fortaleza.

Barros LM (1995) Botânica, origem e distribuição geográfica. In: Araújo JPP, Silva VV (eds), Cajucultura: Modernas Técnicas de Produção, pp.55-72. EMBRAPA/CNPAT, Fortaleza.

Barros LM, Paiva JR, Crisóstomo JR, Cavalcante JJV (2002) Botânica, origem e distribuição geográfica. In: Barros LM (ed), Caju, Produção: Aspectos Técnicos, pp.18-20. Embrapa Informação Tecnológica, Brasília.

Bewley JD, Black M (1994) Seeds, physiology of development and germination. $2^{\text {nd }}$ ed. Plenum Press, New York.

Bezerra FC, Fragoso HA, Hernandez FFF (1999) Avaliação do estado nutricional de cajueiro anão-precoce, clones CP-76 e CP-09. Rev. Bras. Frut. 21:208-211.

Bezerra IL, Gheyi HR, Fernandes PD, Santos FJS, Gurgel MT, Nobre RG (2002) Germinação, formação de portaenxertos e enxertia de cajueiro anão-precoce sob estresse salino. Rev. Bras. Eng. Agric. Amb. 6:420-424.

Bezerra MA, Lacerda CF, Prisco JT, Gomes-Filho E (2005) Crescimento e fotossíntese de plantas jovens de cajueiro anão-precoce crescidas sob estresse salino. Rev. Bras. Eng. Agric. Amb. 9:90-94.

Bezerra MA, Santos FIS, Moraes HMM, Lacerda CF, Gomes-Filho, E (2002) Fotossíntese de cajueiro anão precoce submetido a estresse salino. In: Annals of the XVII Congresso Brasileiro de Fruticultura. Belém, Brazil, CD Room.

Blaikie SJ, Chacko EK (1998) Sap flow, leaf gas exchange and chlorophyll fluorescence of container-grown cashew (Anacardium occidentale L.) trees subjected to repeated cycles of soil drying. Aust. J. Exp. Agric. 38:305-311.

Carneiro PT, Fernandes PD, Gheyi HR, Soares FAL (2002) Germinação e crescimento inicial de genótipos de cajueiro anão-precoce em condições de salinidade. Rev. Bras. Eng. Agric. Amb. 6:199-206.

Cavalcanti Junior AT (1994) Morfo-fisiologia da germinação e estabelecimento da plântula do cajueiro anão-precoce. Lavras, Escola Superior de Agricultura de Lavras. Ph.D. thesis.

Chartzoulakis K, Klapaki G (2000) Response of two greenhouse pepper hybrids to $\mathrm{NaCl}$ salinity during different growth stages. Sci. Hort. 86:247-260.

Chaves MM (1991) Effects of water deficits on carbon assimilation. J. Exp. Bot. 42:1-16.

Crisóstomo LA, Rosseti AG, Pimentel CRM, Barreto PD, Lima RN (2004) Produtividade, atributos industriais e avaliação econômica de castanha em cajueiro-anão precoce adubado com doses crescentes de nitrogênio e potássio, em cultivo sob sequeiro. Rev. Ciên. Agron. 35:87-95.

Crisóstomo LA, Rossetti AG, Pimentel CRM, Barreto PD, Lima RN (2005) Produtividade, avaliação econômica, teores foliares de nitrogênio e potássio e atributos industriais de castanha em cajueiro anão-precoce adubado com doses crescentes de nitrogênio e potássio em cultivo sob sequeiro. In: Yamada $\mathrm{T}$, Roberts TL (eds), Potássio na Agricultura, pp.823-831. Potafos, Piracicaba.

Domènech R, Vilà M (2008) Cortaderia selloana seed germination under different ecological conditions. Acta Oecol., in press.

EMBRAPA, Centro Nacional de Pesquisa de Solos (1999) Sistema Brasileiro de Classificação de Solos. Embrapa Produção da Informação, Brasília; Embrapa Solos, Rio de Janeiro.

FAO (2006) Comercio - cultivos y ganados primários y derivados - caju. Available in $<$ http://www.apps.fao. org $>$.

FAO (2007) The FAOSTAT core production data. Available in: <http://faostat.fao.org $>$.

Flexas J, Bota J, Loreto F, Cornic C, Sharkey TD (2004) Diffusive and metabolic limitations to photosynthesis under drought and salinity in $\mathrm{C}_{3}$ plants. Plant Biol. 6:269-279.

Fragoso HA, Bezerra FC, Melo FIO, Hernandez FFF (1999) Exportação de macronutrientes pela castanha e pseudofruto de dois clones de cajueiro anão-precoce. Rev. Bras. Ciên. Solo 23:603-608.

Franco JA, Esteban C, Rodriguez CE (1993) Effects of salinity on various growth stages of muskmelon cv. Revigal. J. Hort. Sci. 68:899-904.

Gomes Filho E, Prisco JT (1983) Effects of NaCl salinity in vivo and in vitro on ribonuclease activity of Vigna unguiculata cotyledons during germination. Physiol. Plant. 59:183-188.

Glosh SN (1989) Effect of nitrogen, phosphorus and potash on flowering duration, yield and shelling percentage of cashew (Anacardium occidentale L.). Indian Cashew J. 19:14-21. 
Guilherme EA (2006) Desenvolvimento de plantas de cajueiro anão precoce (Anacardium occidentale L.) irrigadas com águas salinas. Fortaleza, Universidade Federal do Ceará. M.Sc. dissertation.

Katembe WJ, Ungar IA, Mitchell JP (1998) Effect of salinity on germination and seedling growth of two Atriplex species (Chenopodiaceae). Ann. Bot. 82:167175.

Kaya MD, Okçu G, Atak M, Çikili Y, Kolsarici O (2006) Seed treatments to overcome salt and drought stress during germination in sunflower (Helianthus annuus L.). Eur. J. Agron. 24:291-295.

Kayani SA, Naqvi HH, Ting IP (1990) Salinity effects on germination and mobilization of reserves in jojoba seed. Crop Sci. 30:704-708.

Kozlowski TT (1997) Responses of woody plants to flooding and salinity. Tree Physiol. Monograph. 1:129.

Kramer PJ, Boyer JS (1995) Water Relations of Plants and Soils. Academic Press, San Diego.

Kumar PH, Nair BP, Rakhiappan P, Nagabhushanam S, Mohan E (1982) Variation in mineral composition of leaves of cashew (Anacardium occidentale L.) as affected by season, position and age. Indian Cashew J. 14:7-10.

Lacerda CF (2005) Interação salinidade x nutrição mineral. In: Nogueira RJMC, Araújo EL, Willadino LG, Cavalcante UMT (eds.), Estresses Ambientais: Danos e Benefícios às Plantas, pp.127-137. Sociedade Brasileira de Fisiologia Vegetal, Recife.

Lawlor DH ( 2002) Limitation to photosynthesis in waterstressed leaves: stomata vs metabolism and the role of ATP. Ann. Bot. 89:275-294.

Lima MA, Enéas-Filho J, Bezerra MA, Pinto CM (2007) Respostas fotossintéticas de dois clones de cajueiro anão precoce sob cultivo irrigado e não irrigado. In: Annals do XI Congresso Brasileiro de Fisiologia Vegetal. Gramado, Brazil, CD Room.

Lima RLS, Oliveira VH, Fernandes VLB, Hernandez FFF (2003) Acúmulo de N, K, Ca, Mg e S na matéria seca da parte aérea de mudas de cajueiro-anão-precoce submetidas a níveis crescentes de matéria orgânica. Rev. Bras. Frut. 25:148-151.

Marschner H (1995) Mineral nutrition of higher plants. $2^{\text {nd }}$ ed. Academic Press, San Diego.

Maas EV, Hoffman GJ (1977) Crop salt tolerance-current assessment. J. Irrig. Drain. Div. 103:115-134.

Mayer AM, Poljakoff-Mayber A (1989) The germination of Seeds. $4^{\text {th }}$ ed. Pergamom Press, Oxford.

Mesquita RO, Bezerra MA, Lacerda CF, Gomes-Filho E (2007) Desenvolvimento e distribuição de íons em plântulas de cajueiro anão precoce cultivadas em diferentes substratos e submetidas ao estresse salino. In: Annals do Workshop Manejo e Controle da Salinidade na Agricultura Irrigada. Recife, Brazil, CD Room.

Mitchel JD, Mori SA (1987) The cashew and its relatives (Anacardium: Anardiaceae). Mem. N. Y. Bot. Gard. 42:1-76.

Munns R (1993) Physiological processes limiting plant growth on saline soils: some dogmas and hypotheses. Plant Cell Environ. 16:15-24.

Munns R, Termaat A (1986) Whole-plant responses to salinity. Aust. J. Plant Physiol. 13:143-160.

Murillo-Amador B, López-aguilar R, Kaya C, LarrinagaMayoral J, Flores-Hernández A (2002) Comparative effects of $\mathrm{NaCl}$ and polyethylene glycol on germination, emergence and seedlings growth of cowpea. J. Agron. Crop Sci. 188:235-247.

Oliveira MSC (2001) Estudo da composição lipídica e efeito do estresse hídrico em membranas foliares de cajueiro anão precoce (Anacardium occidentale L.). Fortaleza, Universidade Federal do Ceará. M.Sc. dissertation.

Oliveira VH, Miranda FR, Lima RN, Cavalcante RRR (2006) Effect of irrigation frequency on cashew nut yield in northeast brazil. Sci. Hort. 108:403-407.

Paiva JR, Cavalcanti JJV, Barros LM, Crisóstomo JR (2003) Clones. In: Barros LM (ed), Caju, Produção: Aspectos Técnicos, pp.74-78. Embrapa Informação Tecnológica, Brasília.

Pelleschi S, Rocher J-P, Prioul J-L (1997) Effect of water restriction on carbohydrate metabolism and photosynthesis in mature maize leaves. Plant Cell Environ. 20:493-503.

Prisco JT, O’ Leary JW (1970) Osmotic and "toxic" effects of salinity on germination of Phaseolus vulgaris L. seeds. Turrialba 20:177-184.

Prisco JT, Eneas Filho J, Gomes Filho E (1981) Effect of $\mathrm{NaCl}$ salinity on cotyledon starch mobilization during germination of Vigna unguiculata (L.) Walp seeds. Rev. Brasil. Bot. 4:63-71. 
Richards LA (1954) Diagnosis and Improvement of Saline and Alkali Soils. (Handbook $n^{\circ} 60$ ). US Dept. Agriculture, Washington.

Richards NK (1993) Cashew response to water and nutrients in a sandy red earth soil of the Northern Territory. In: Department of Primary Industry and Fisheries, Cashew Research in Northern Territory, pp.17-38. Department of Primary Industry and Fisheries, Darwin Northern Territory. (Technical Bulletin No. 202).

Schaper H, Chacko EK, Blaike SJ (1996) Effect of irrigation on leaf gas exchange and yield of cashew in northern Australia. Aust. J. Exp. Agric. 36:861-868.

SECEX (2007) Sistema aliceweb. Available in: < http: // www.aliceweb.desenvolvimento.gov.br>.

Sharma S, Amritphale D (2008) Light environment in preand post-dehiscent fruits affects seed germination in Calotropis procera. Environ. Exp. Bot. 62:45-53.

Taiz L, Zeiger E (2002) Plant Physiology. $2^{\text {nd }}$ ed. Sinauer Associates, Massachusetts.

Tommasia F, Paciollaa C, Pintoa MC, Garaa L (2006) Effects of storage temperature on viability, germination and antioxidant metabolism in Ginkgo biloba L. seeds. Plant Physiol. Biochem. 44:359-368.

Torres SB, Vieira EL, Marcos-Filho J (2000) Efeitos da salinidade na germinação e no desenvolvimento de plântulas de pepino. Rev. Bras. Sem. 22:39-44.

Trelease RN, Doman DC (1984) Mobilization of oil and wax reserves. In: Murray DR (ed), Seed Physiology: Germination and Reserve Mobilization, pp.201-245. Academic Press, New York.

Viégas RA, Silveira JAG, Lima Junior AR, Queiroz JE, Fausto MJM (2001) Effects of NaCl-salinity on growth and inorganic solute accumulation of young cashew plants. Rev. Bras. Eng. Agric. Amb. 5:14-20.

Viégas RA, Silveira JAG, Silva LMM, Viégas PRA, Queiroz JE, Rocha IMA (2004) Redução assimilatória de nitrato em cajueiros cultivados em meio salinizado. Rev. Bras. Eng. Agric. Amb. 8:189-195.

Vieira MR, Lacerda CF, Cândido MJD, Carvalho PL, Costa RNT, Tabosa JN (2005) Produtividade e qualidade da forragem de sorgo irrigado com águas salinas. Rev. Bras. Eng. Agric. Amb. 9:42-46.

Ximenes, CHM (1995) Adubação mineral de mudas de cajueiro anão precoce cultivadas em diferentes substratos. Fortaleza, Universidade Federal do Ceará. M.Sc. dissertation.

Zhu JK (2001) Plant salt tolerance. Trends Plant Sci. 6:6671. 